\title{
Species Diversity and Structure of an Intact Freshwater Swamp Forest in the Niger Delta
}

\author{
Nwabueze I. Igu \\ Department of Geography and Meteorology, Nnamdi Azikiwe University, Awka, Nigeria \\ Email: nwabuezeigu@gmail.com
}

How to cite this paper: Igu, N. I. (2017). Species Diversity and Structure of an Intact Freshwater Swamp Forest in the Niger Delta. Open Journal of Forestry, 7, 242-254. https://doi.org/10.4236/ojf.2017.72015

Received: February 10, 2017

Accepted: April 15, 2017

Published: April 18, 2017

Copyright $\odot 2017$ by author and Scientific Research Publishing Inc. This work is licensed under the Creative Commons Attribution International License (CC BY 4.0).

http://creativecommons.org/licenses/by/4.0/

\begin{abstract}
Tropical forest ecosystems are generally seen as diverse ecosystems with rich biodiversity. However, how this applies to the freshwater swamp forests (especially in West Africa) is largely unknown. To verify how diverse this ecosystem is and how its structure varies in an intact forest landscape, one hectare forest plots were set up at 8 different points. This was used to collect information on the diversity and structure of the ecosystem. Consistent with the findings from other freshwater swamp forests, the ecosystem was seen to have a low species occurrence which ranged from 4 to 19 (mean value $=11$ species) across the forest plots. Its diversity was equally low (mean $=1.66$ ), unlike other tropical forest ecosystems. Stem heights varied as in mature tropical forest ecosystems; with the middle stratum recording the highest proportion of trees $(54.63 \%)$ and the emergent layer having the least $(0.83 \%)$. Its basal area, biomass and relative density were similar with other tropical ecosystems and equally had its highest species contribution from Leguminosae as in some other ecosystems as well. The ecosystem was seen to have features and characteristics that were common and similar with other tropical forest ecosystems, apart from its low diversity. Ensuring that effective and appropriate forest-tree species conservation measures are enhanced across the landscape are vital steps to securing the already existing (few) species and preventing species extinction across the ecosystem.
\end{abstract}

\section{Keywords}

Biodiversity, Conservation, Forest Disturbance, Forest Management, Species Richness, Swamp Forests

\section{Introduction}

Tree species in tropical forests are varied at different spatial scales and characterized with high diversity across the Tropics and Neotropics. This could be broadly estimated to be more than 100 species per hectare (Gentry, 1990; Huang 
et al., 2003), or specifically seen to range between 56 and 283 (>10 cm DBH) in mature tropical forests (Philips \& Gentry, 1994) and 300 or more species of trees $(\geq 10 \mathrm{~cm} \mathrm{DBH})$ per hectare in the Neotropics (Gentry, 1988; Valencia et al., 1994; Huang et al., 2003; Kelloff, 2008). The dominant species have been reported to vary from place to place; from Leguminosae in Neotropical lowland forests and African lowland forests, to Dipterocarps in Southeast Asia (Gentry, 1988; Whitmore, 1998; Huang et al., 2003). Though the African forests are composed of large tree biomass, its diversity has been reported to be relatively poor compared to higher diversities in Asian and American forests (Parmentier et al., 2007; Chuyong et al., 2011; Malhi et al., 2013). While this could be attributed to climate (mainly annual rainfall and rainfall seasonality) (Francis \& Currie, 2003; Field et al., 2005; Parmentier et al., 2007), a good baseline is yet to be established for its diversity as only few systematic studies have been conducted in the region regarding the basic attributes such as biomass, species diversity and structure (Parmentier et al., 2007; Chuyong et al., 2011; Gourlet-Fleury et al., 2013; Malhi et al., 2013; Peh et al., 2014). While some studies in Nigeria have enumerated the diversity and species composition of different forest sites (Ihenyen et al., 2009; Ihuma et al., 2011; Adekunle et al., 2013; Ogbemudia et al., 2013; Udofia et al., 2014), studies that systematically showed the species diversity and structural baselines with particular reference to the freshwater swamp ecosystem are still much needed.

The freshwater swamp forests are moist forests found in freshwater environments. Though they are found in tropical rainforest regions, its species diversity is varied from that of the lowland forests (which supports a higher diversity of plant species) on account of constraints in dispersal, germination and establishment, due to its seasonal extremes (Lopez \& Kursar, 2007; Corlett \& Primack, 2011). This ecosystem is instead characterized by lower diversity and strong dominance of few tree species (Bacon, 1990; Richards, 1996; Koponen et al., 2004). Within the ecosystem, the flora is equally varied according to site conditions, inundation and floral history (Fickert \& Grüninger, 2010), disturbance regimes, land use and water quality. Since the ecosystem offer veritable uses like groundwater recharge, water quality improvement, floral and faunal habitat and varieties of ecosystem services ranging from provisioning to regulatory services, understanding its diversity at different scales are important. With increased forest degradation, especially by selective logging and large scale human-induced changes that are altering and modifying the forest landscapes of the Niger Delta region, there is need to understand the diversity and structure of the freshwater swamp forest ecosystem. Forest degradation in Nigeria has accelerated due to recent development activities, population increase and agricultural expansion. Such degradations have not only fragmented the ecosystem and left it as forest mosaics and islands, but equally reduced its capacity to provide vital ecosystem functions. With a continuous trend in forest degradation continuing across the ecosystem, there is need to document its biodiversity and patterns. This work is aimed at understanding the species diversity of the ecosystem across intact forest 
landscapes, as well as its structural patterns. Understanding these patterns are important and useful for providing baseline information on community coexistence, stability and ecosystem functions that will be vital to underpin future management, use and abstraction for the ecosystem.

\section{Materials and Methods}

\subsection{Study Site}

The study was carried out in Otuwe forest (Figure 1) - an intact forest location in the flood forest freshwater swamp forests of the Niger Delta. This forest land is owned by the Akarai-Obodo community and accessible mainly during the dry season due to poor accessibility (no access roads or waterway connecting it to the community or elsewhere). The community as well as the forest is located in Ndokwa East Local Government Area of Delta state, Nigeria (Figure 1). The forest which is named after a lake, is found in the Niger basin of Nigeria and is made up of marine sediments of the upper and lower cretaceous age. Being
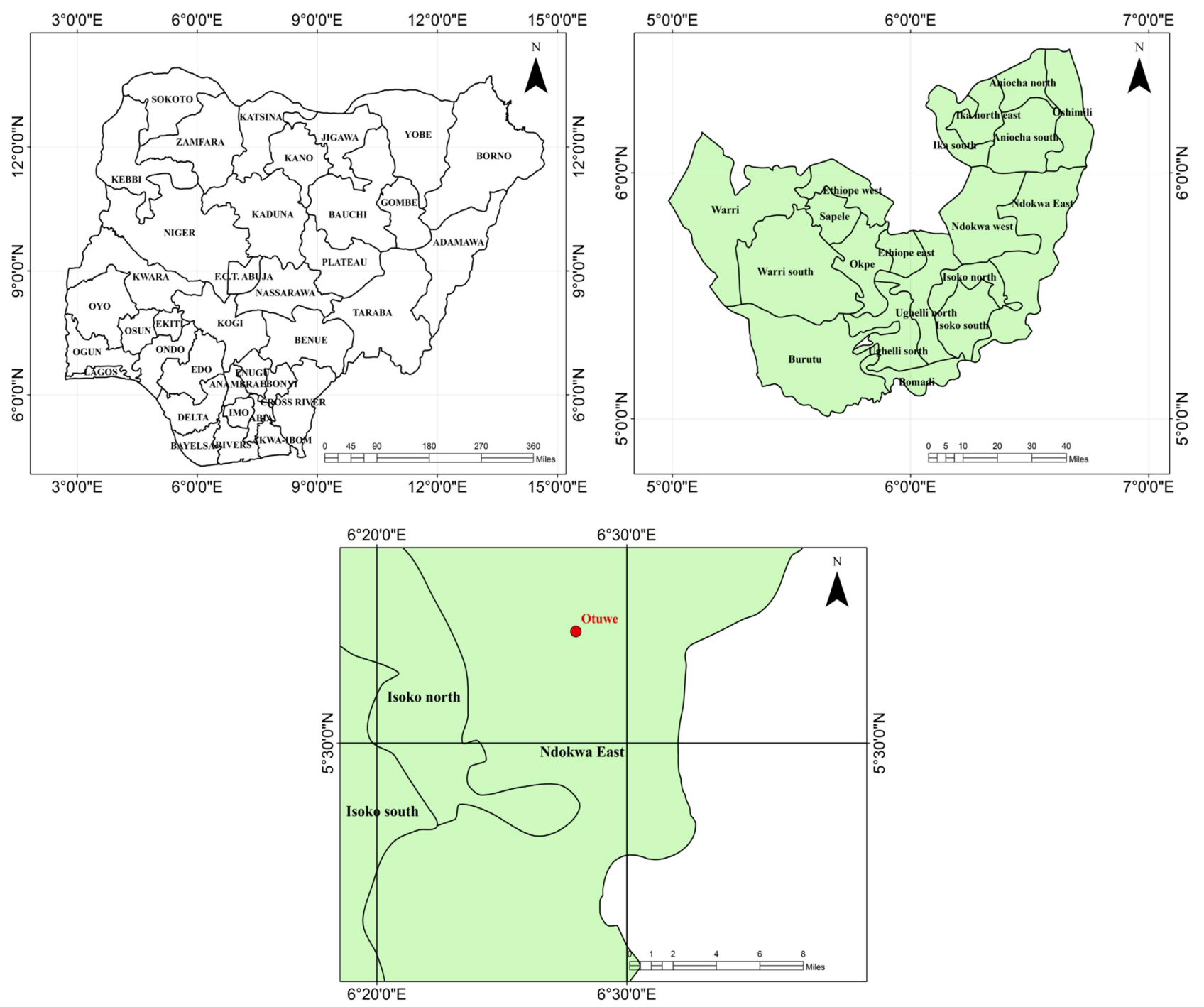

Figure 1. Map of the study site. 
categorized broadly as hydromorphic soils (Areola, 1982), the soils are characterized by both the seasonally and permanently waterlogged soils; which are uniformly alluvial. The study region is a vast sedimentary region and flat area that is criss-crossed by a large number of meandering streams and creeks. It has a tropical climate with long rainy season, relative humidity which rarely dips below $60 \%$ and an average monthly maximum and minimum temperatures varying between $28^{\circ} \mathrm{C}$ to $33^{\circ} \mathrm{C}$ and $21^{\circ} \mathrm{C}$ to $23^{\circ} \mathrm{C}$, respectively. The flood regime of the region begins toward the end of the rainy season in August, peaks in October, and tapers off in December.

The freshwater swamp forest of the Niger Delta is the most extensive and largest across Nigeria and West Africa (NDES, 1997; Spalding et al., 2010). It is divided into the seasonally flooded and permanently flooded zones. The ecosystem has transition zones with the lowland rainforest and mangrove ecosystems in the northern and southern parts of the ecosystem respectively. The region has been inhabited since about 5000 Years before present (YBP) (Nzewunwa, 1985) and much of the forest ecosystem have been exploited for timber production, industrial activities and domestic functions, mainly as sources of firewood and charcoal. Much of the forest in this region has been converted into plantation farms and overtaken by urbanization and industrial activities-mainly crude oil exploration. The ecosystem is threatened by salt water intrusion from the canalization and crude oil prospecting activities in the region, dredging and land reclamation, and population pressure.

\subsection{Vegetation Data Collection}

Standard plot-based method, which involves a one-time census of all stems $\geq 10$ $\mathrm{cm}$ in diameter using a 1 ha square shaped (Phillips et al. 2003; Newton, 2007) was employed for this work between December 2013 and April 2014. Each of the 1 hectare square plots were established on transects that were $1 \mathrm{~km}$ wide apart, and contained plots of $100 \times 100 \mathrm{~m}$ each at the interval of $500 \mathrm{~m}$ between each of the plots. The interval between the plots and transects were to ensure that there is a sizeable distance to enable floristic variation, yet maintaining consistency. All stems $\geq 10 \mathrm{~cm}$ in diameter at breast height $(130 \mathrm{~cm})$ were analysed and smaller ones omitted in order to ensure that species identification had minimal bias. Stem heights was determined using a laser rangefinder and where the tree height was less than 10 meters, graduated poles was used in measuring the height. Tree species were identified in the field by a trained taxonomist from the Forestry Research Institute, Ibadan (FRIN), while the specimen for the unidentified ones were collected and verified at FRIN herbarium. Specie identification followed the taxonomy of Nigerian plants (Keay, 1989).

\subsection{Data Analyses}

\subsubsection{Forest Structure Analyses}

In order to characterize the forest sites, the importance values of the species (species importance values) and the families (family importance values) were 
calculated after Cottam and Curtis (1956), Mori et al. (1983) and Husch et al. (2003) as follows:

$$
\begin{aligned}
& \text { Relative Density }=100 \times \frac{\text { Number of stems of a species }}{\text { Total number of stems }} \\
& \text { Relative frequency }=100 \times \frac{\text { Frequency of a species }}{\text { Sum of all species }} \\
& \text { Relative dominance }=100 \times \frac{\text { Total basal area of a species }}{\text { Total basal area of all species }} \\
& \text { Species importance values (SIV) = Relative density + Relative frequency } \\
& + \text { Relative dominance } \\
& \text { Relative diversity }=100 \times \frac{\text { Number of species in a family }}{\text { Total number of species }} \\
& \text { Family importance values (FIV) }=\text { Relative density }+ \text { Relative dominance } \\
& + \text { Relative diversity }
\end{aligned}
$$

Dominance was defined as species or families with ecological values $\geq 10$ for this study.

\subsubsection{Basal Area}

The basal area was calculated as follows:

$$
B A=\left(\frac{d b h}{2}\right)^{2} \times \pi
$$

where $B A$ is the basal area $\left(\mathrm{m}^{2}\right)$; dbh is the diameter at breast height $(\mathrm{cm})$ and $\pi$ as pie (3.142).

The stem sizes were categorized into the following forest structural analysis: small (10 - $20 \mathrm{~cm} \mathrm{dbh);} \mathrm{medium} \mathrm{(21} \mathrm{-} \mathrm{50);} \mathrm{large} \mathrm{(51} \mathrm{-} \mathrm{100)} \mathrm{and} \mathrm{largest} \mathrm{(>100)}$ (Adekunle et al., 2013). Heights of the trees were categorized into classes using an interval of $5(\leq 5,6-10,11-15, \ldots)$ and used to plot a graph to depict the vertical structural pattern of the forest.

\subsubsection{Species Diversity Analyses}

The diversity indices were calculated following Kent and Coker (1992), Magurran (1998) and Magurran (2004) as follows:

Shannon-Wiener index:

$$
H^{\prime}=-\sum_{i=1}^{s} p i \ln p i
$$

where $H^{l}$ is the Shannon-Weiner index, $s$ is the total number of species, $p i$ is the proportion of individuals in the ith species, and $\ln$ is the natural logarithm.

Pielou's evenness index:

$$
E=\frac{\sum_{i=1}^{s} p i \ln p i}{\ln (S)}
$$

Margalef's species richness index: 


$$
M=\frac{(S-1)}{\ln N}
$$

where $\mathrm{S}$ is the total number of species in a community, $N$ is the number of individuals and $\ln$ is the natural logarithm.

Pearson correlation was used to show the relationship that existed among the biodiversity indices using IBM SPSS software version 20.

\section{Results}

\subsection{Floristic Composition, Abundance and Dominance}

This forest ecosystem is composed of 35 species within 28 genera and 18 families. The number of species found across the 8 plots in the forest site ranged from its lowest of 4 species found in plot 3 to the highest number (19) found in plot 4 . The average abundance of the species across the forest was concentrated on four species: Celtis zenkeri Engl, Diospyros mespiliformis Hochst, Sterculia oblonga Mast and Sterculia rhinopetala K. Schum; which contributed $92.89 \%$ (Table 1) of the total species occurrence, while the remaining $7.10 \%$ were from the other 31 species in the forest. Among the 35 species present in the forest, the dominant species across the forest site were: Diospyros mespiliformis, Sterculia oblonga, Sterculia rhinopetala, Celtis zenkeri Engl and Erythrophleum ivorense A. Chev, with species importance values of 83.61, 66.29, 35.51, 26.32 and 13.31 respectively. The dominant families (family importance value) across the forest site were: Malvaceae, Ebenaceae, Leguminosae and Cannabaceae, with importance values of $106.93,72.36,40.51$ and 20.75 respectively.

\subsection{Species Diversity and Rarity}

The species found in the ecosystem had a total of 2043 (stems) occurrences across the 8 plots. The pattern of species occurrence varied from the species that had $>100$ stems $(14.28 \%),>1<100$ stems $(62.85 \%)$, and those with only a single stem occurrence $(22.85 \%)$. Leguminosae had the highest number (9) of species and was followed by Malvaceae (5); Moraceae (3); Annonaceae, Apocynaceae, Ebenaceae and Olacaceae (2 species each), while the remaining families were represented by one species each (Table 2 ).

The species diversity across the site was low: with the highest species diversity (2.13) seen in plot 1 and the least diversity of 0.98 in plot 3 ; and a mean value of 1.66 (Table 3). Pielou's evenness index ranged from 0.83 to 0.55 (Table 3), while the mean value across the site was 0.72 . Margalef's species richness index ranged

Table 1. Summary of the abundance and characterizing species across the sites.

\begin{tabular}{ccccc}
\hline Species & Ave. Abundance & Ave. Similarity & \% Contribution & Cumulative \% \\
\hline Diospyros mesipiliformis & 94.75 & 22.1753 & 45.3885 & 45.3885 \\
Sterculia oblonga & 36.25 & 10.6965 & 21.8937 & 67.2822 \\
Sterculia rhinopetala & 34.125 & 8.62638 & 17.6565 & 84.9387 \\
Celtis zenkeri & 39.5 & 3.8888 & 7.95961 & 92.8983 \\
\hline
\end{tabular}


Table 2. Number of species per family across the forest site.

\begin{tabular}{|c|c|}
\hline Family & Number of species \\
\hline Annonaceae & 2 \\
\hline Apocynaceae & 2 \\
\hline Arecaceae & 1 \\
\hline Cannabaceae & 1 \\
\hline Chrysobalanaceae & 1 \\
\hline Combretaceae & 1 \\
\hline Ebenaceae & 2 \\
\hline Gentianaceae & 1 \\
\hline Lecythidaceae & 1 \\
\hline Leguminosae & 9 \\
\hline Malvaceae & 5 \\
\hline Meliaceae & 1 \\
\hline Moraceae & 3 \\
\hline Myristicaceae & 1 \\
\hline Olacaceae & 2 \\
\hline Rhizophoraceae & 1 \\
\hline Rubiaceae & 1 \\
\hline Sapindaceae & 1 \\
\hline
\end{tabular}

Table 3. Biodiversity indices across the forest site.

\begin{tabular}{ccccccc}
\hline $\begin{array}{c}\text { Plot } \\
\text { number }\end{array}$ & $\begin{array}{c}\text { Margalef } \\
\text { index }\end{array}$ & $\begin{array}{c}\text { No of } \\
\text { stems }\end{array}$ & Diversity & Evenness & Singleton & $\begin{array}{c}\text { No. of } \\
\text { species }\end{array}$ \\
\hline 1 & 2.47 & 128 & 2.13 & 0.83 & 3 & 13 \\
2 & 1.43 & 264 & 1.78 & 0.81 & 2 & 9 \\
3 & 0.52 & 304 & 0.98 & 0.7 & 0 & 4 \\
4 & 3.26 & 250 & 1.88 & 0.64 & 7 & 19 \\
5 & 2.16 & 409 & 1.44 & 0.55 & 4 & 14 \\
6 & 1.34 & 183 & 1.47 & 0.71 & 2 & 8 \\
7 & 1.91 & 310 & 1.85 & 0.75 & 1 & 12 \\
8 & 1.71 & 193 & 1.76 & 0.77 & 2 & 10 \\
\hline
\end{tabular}

from 0.52 to 3.26; with a mean value of 1.85. Mean number of species recorded across the plots was 11 (which ranged from 4 to 19 species) (Table 3 ).

The pattern of species rarity across the forest showed the highest value of 7 single (rare) species and a no occurrence value (0) as its least. On the average, the pattern of rarity across the forest site was low (2.62).

The results of the Pearson correlation coefficient (significant at 0.05 levels) showed that species richness correlated with species diversity and rarity. How- 
ever, the highest correlation ( $\mathrm{r}$ value) of 0.78 was between species richness and species rarity, an average correlation of 0.48 between species richness and diversity, and no significance between species richness and evenness.

\subsection{Forest Structure}

The highest total basal area of 30,995.62 $\mathrm{m}^{2}$ was contributed by Sterculia oblonga, followed by Diospyros mespiliformis $\left(29,214.11 \mathrm{~m}^{2}\right)$ and Sterculia rhinopetala $\left(10,397.52 \mathrm{~m}^{2}\right)$, respectively. The least basal area per hectare $\left(0.0086 \mathrm{~m}^{2}\right)$ was contributed by Elaeis guineensis, while the highest basal area (stem size) across the forest was $448 \mathrm{~cm}$ (as seen in Celtis zenkeri).

Ebenaceae had the highest relative density (38.17) across the forest and was followed by Malvaceae (29.98). However, Malvaceae had the highest total basal area of $79,107.98 \mathrm{~m}^{2}$ and was followed by Ebenaceae with $34,419.65 \mathrm{~m}^{2}$. Annonaceae had the highest mean dbh of $118.9 \mathrm{~cm}$, followed by Malvaceae $(55.79$ $\mathrm{cm})$, while Arecaceae had the least mean dbh $(10.5 \mathrm{~cm})$. Sterculia oblonga had the highest dbh (dominant $\mathrm{dbh}$ ) of $19,870.8 \mathrm{~cm}$, while Elaeis gunieensis and Millettia thonningii had the least dbh $(10.5 \mathrm{~cm})$. Diospyros mespiliformis had the highest mean height of $837.81 \mathrm{~m}$, the tallest single tree in the forest was 82.5 $\mathrm{m}$ (Cleistopholis patens Engl. \& Diels) and the mean height for the entire forest was $15.61 \mathrm{~m}$.

The stem height intervals had variations in the number of stems per class, as expected in mature forests. While stem heights between $11-15 \mathrm{~cm}$ recorded the highest number of stems (662), the least value of 2 was found in the highest stem interval ( $\geq 46 \mathrm{~cm}$ ) (Figure 2). The highest proportion $(54.63 \%)$ of the trees in the forest occupied the middle stratum $(11-25 \mathrm{~cm})$, followed by the lower stratum $(\leq 10 \mathrm{~cm})(30.76 \%)$ and upper stratum $(26-40 \mathrm{~cm})(13.76 \%)$. The emergent layer $(>40 \mathrm{~cm})$ occupied the least value $(0.83 \%)$ (Figure 2$)$.

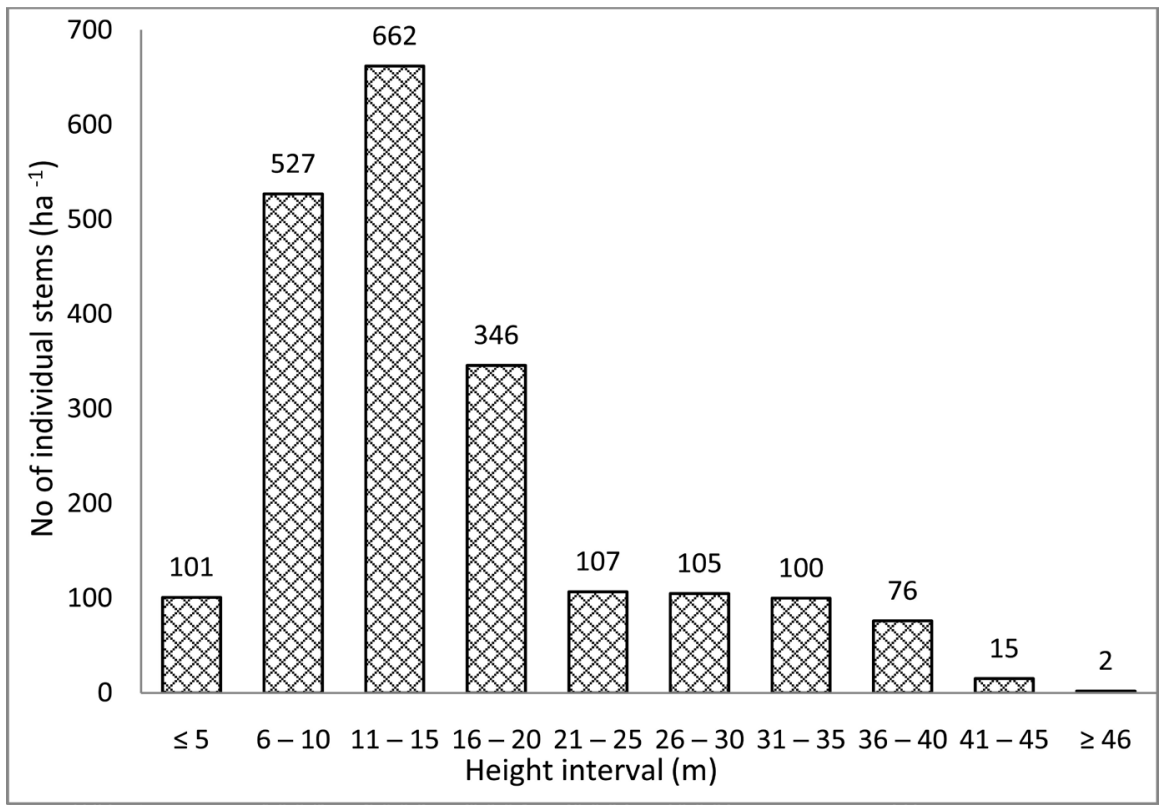

Figure 2. Height intervals of individual stems per hectare. 


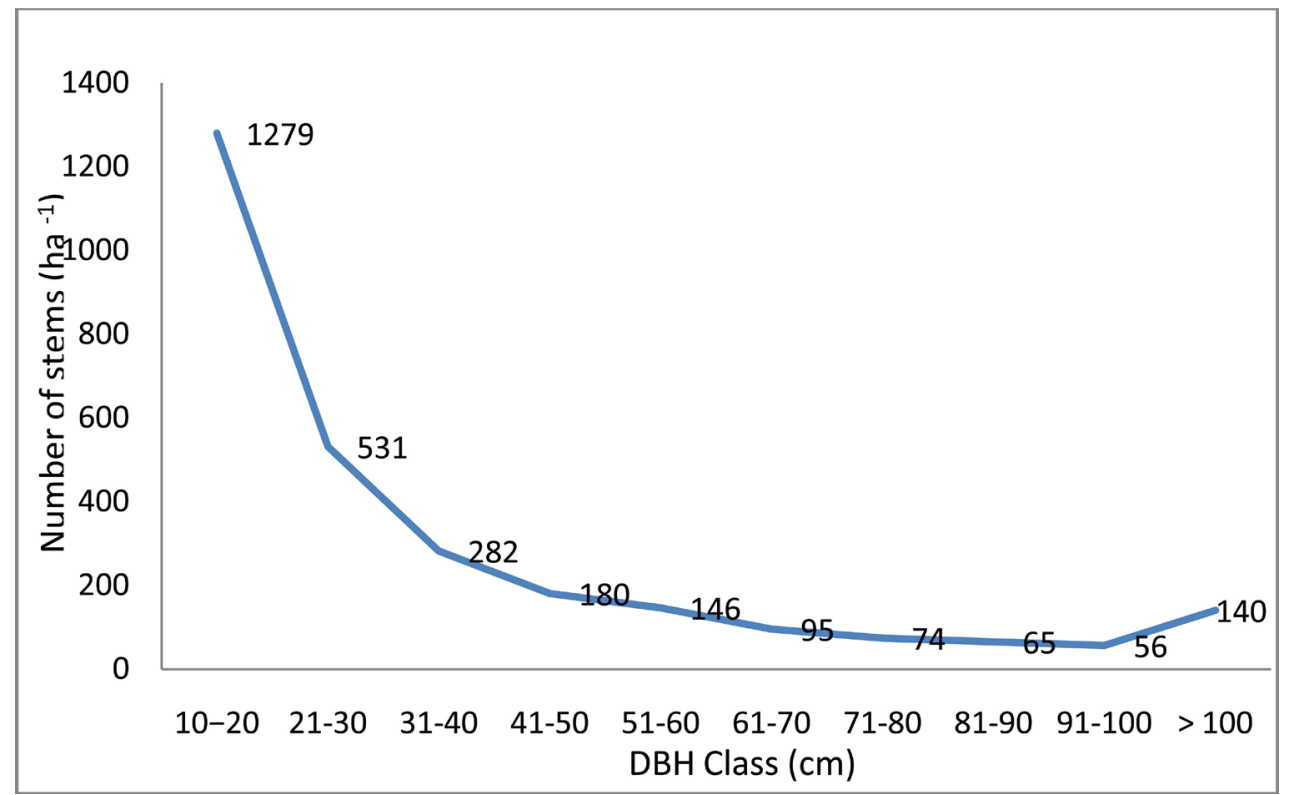

Figure 3. Diameter class of trees in the forest.

The pattern of distribution of the basal area of the forest had the highest values (dbh) from the lower class to the higher ones. The highest numbers of stems (1279) in the forest were found in dbh class of $10-20 \mathrm{~cm}$, and reduced as the dbh classes increased consistently until the $91-100 \mathrm{~cm}$ dbh class (Figure 3 ). It however, experienced another increase in the number of stems for the $>100 \mathrm{~cm}$ dbh class (Figure 3 ). The number of stems in the forest was inversely proportional to the diameter sizes, shown by the reverse J (curve) pattern of the dbh interval distribution (Figure 3). This showed that the forest had a balanced species regeneration and recruitment.

\section{Discussion}

The freshwater swamp forest ecosystem in the Niger Delta is an ecologically important biome with unique biodiversity of regional and local importance. However, unlike other tropical forest ecosystems with higher species richness such as the Neotropics which records as much as 300 species per hectare (Gentry, 1988) and other African forests where the species richness is even as low as 60 species per hectare (Bernhard-reversat et al., 1978); it is much lower. Hence, while the forest recorded as much as 35 species across the entire forest plots, its abundance and dominance is concentrated only on four species. Though its mean species richness is far below other forest ecosystems both in Africa and across the Amazonia (Gentry, 1988; Phillips \& Gentry, 1994; Richards, 1996; Ndah et al., 2013), it is similar with other freshwater swamp forests which are taken to be species poor as well (Scarano et al., 1997; Kurtz et al., 2013). While this could be generally attributed to the variations that exist in their abiotic environment, history and biogeography (Orians et al., 1996), it is equally as a result of the environmental constraints associated with the ecosystem. On the other hand, the diversity of the forest ecosystem was equally low, with a 
mean value that is far lesser than other tropical forest ecosystems (Knight 1975; Duran et al., 2006). This low diversity across the ecosystem, as in other swamp forests across the tropics, is not only due to the oxygen stress that plants in such flooded terrains go through, but also due to the fragmented nature of such landscapes (van Andel, 2003). Even though such disturbances and fragmentation of the ecosystem are expected to enable the gap dynamics that would facilitate a higher diversity across the landscape, the rare species that eventually thrive in the ecosystem are limited and quite few. This understanding that new species recruitment and establishment is constrained by the environment is not only beneficial for establishing guidelines and restraints targeted at protecting and conserving rare species, but also useful in promoting the functional diversity of the ecosystem.

The forest structure of the ecosystem was mainly influenced by the dominant species which had the higher basal area and relative density. With a high evenness, though with a low diversity, the forest's community structure was able to attain a mature and stable status; evidenced by the inverse J-shape. The forest had representative tree stands for each of the structural intervals or categories and a healthy juvenile/middle class tree population size (Figure 3), which is suitable for good recruitment and replacement for the mature and emergent populations. Such mature forests' with large trees are veritable assets in carbon sequestration for the region (Igu \& Marchant, 2016) and useful in providing necessary ecosystem services that support the livelihood of its owners. Tree stems which ranged from 128 - 409 stems per hectare (with a mean of 255) across the forest plots were within the range of 245 - 467 stems per hectare, as reported for other tropical forests (Campbell et al., 1992). Though the mean number of tree stems per hectare was less than the average numbers of 323 trees per hectare (Aigbe et al., 2014), 387 stems per hectare (Adekunle et al., 2013) in tropical forest reserves in Nigeria, it was seen to exhibit an adequate population structure that had both a regenerating and climax population. Its lower tree stem numbers however, is attributed to the disturbances associated with the ecosystem (such as flooding) as well as the biogeography (shallow soil depth) of the region; which promotes tree falls and uprooting of tree stems across the forest ecosystem. Relative density varied across the ecosystem as would in mature forest ecosystems, according to the different families represented in the forest. Ebenaceae had the highest relative density among the families in the forest through its single genus Diospyros (and two species-mespiliformis and crassiflora). With other families such as Malvaceae and Leguminosae with five and nine species respectively, it shows that higher species number does not necessarily translate to a higher relative density in forest ecosystems. On the other hand, while it is likely that a higher frequency of occurrence of species, genus and family across an area (relative density) would translate to a higher total basal area, however, basal area of individual large trees which may be a bit fewer in number (as in the case of Malvaceae) are more likely to record (as much as double the size) a higher cumulative basal area. 


\section{Conclusion}

Species diversity across the ecosystem was found to be low as in other freshwater ecosystems across the globe. As this is mainly as a result of the environmental constraints associated with the swamp (oxygen stress) which limits reproduction and adaptability of most of the plants, caution needs to be applied as it concerns logging in the ecosystem, so that the ecosystem will not become bare of trees or turned to shrubs. Ensuring that only mature trees are logged will help to guarantee a balanced regeneration and recruitment process across the ecosystem, the environmental constraints and low diversity notwithstanding. Such measures are equally needed across other tropical forest ecosystems which are lost at astronomical rates, so as to ensure that such landscapes are preserved and that its species do not become extinct.

\section{References}

Adekunle, V. A. J., Olagoke, A. O., \& Akindele, S. O. (2013). Tree Species Diversity and Structure of a Nigerian Strict Nature Reserve. Tropical Ecology, 54, 275-289.

Aigbe, H. I., Akindele, S. O., \& Onyekwelu, J. C. (2014). Tree Species Diversity and Density Pattern in Afi River Forest Reserve, Nigeria. International Journal of Scientific and Technology Research, 3, 178-185.

Areola, O. (1982). Soils. In K. M. Barbour, J. S. Oguntoyinbo, J. O. C. Onyemelukwe, \& J. C. Nwafor (Eds.), Nigeria in Maps. USA: Africana Publishing Company.

Bacon, P. R. (1990). Ecology and Management of Swamp Forests in the Guianas and Caribbean Region. In A. Lugo, M. Brinson, \& Brown, S. (Eds.), Ecosystems of the world 15. Forested wetlands (pp. 213-250) Amsterdam: Elsevier.

Bernhard-reversat, F., Huttel, C., \& Lemee, G. (1978). Structure and Functioning of Evergreen Rain Forest Ecosystem of the Ivory Coast. In Tropical Forest Ecosystems: A State-of-Knowledge Report (pp. 557-574). Paris: UNESCO.

Campbell, D. G., Stone, J. L., \& Stone, A. (1992). A Comparison of Phytosociology and Dynamics of Three Floodplain (Várzea) Forests of Known Ages, Rio Juruá, Western Brazilian Amazon. Botanical Journal of the Linnaean Society, 108, 213-237. https://doi.org/10.1111/j.1095-8339.1992.tb00240.x

Chuyong, G. B., Kenfack, D., Harms, K. E., Thomas, D. W., Condit, R., \& Comita, L. S. (2011). Habiat Specificity and Diversity of Tree Species in an African Wet Tropical Forest. Plant Ecology, 212, 1363-1374. https://doi.org/10.1007/s11258-011-9912-4

Corlett, R. T., \& Primack, R. B. (2011). Tropical Rain Forests: An Ecological and Biogeographical Comparison (2nd ed.). Hoboken, NJ: Wiley-Blackwell. https://doi.org/10.1002/9781444392296

Cottam, G., \& Curtis, J. T. (1956). The Use of Distance Measurements in Phytosociological Sampling. Ecology, 37, 451-460. https://doi.org/10.2307/1930167

Duran, E., Meave, J. A., Lott, D. J., \& Segura, G. (2006). Structure and Tree Diversity Patterns at Landscape Level in a Mexican Tropical Deciduous Forest. Boletin de Sociedad Botanica de Mexico, 79, 43-60.

Fickert, T., \& Grüninger, F. (2010). Floristic Zonation, Vegetation Structure, and Plant Diversity Patterns within a Caribbean Mangrove and Swamp Forest on the Bay Island of Utila (Honduras). Ecotropica, 16, 73-92.

Field, R., O’Brien, E. M., \& Whittaker, R. J. (2005). Global Models for Predicting Woody Plant Richness from Climate: Development and Evaluation. Ecology, 86, 2263-2277. 
https://doi.org/10.1890/04-1910

Francis, A. P., \& Currie, D. J. (2003). A Globally Consistent Richness-Climate Relationship for Angiosperms. The American Naturalist, 161, 523-536.

https://doi.org/10.1086/368223

Gentry, A. H. (1988). Changes in Plant Community Diversity and Floristic Composition on Environmental and Geographical Gradients. Annals of the Missouri Botanical Garden, 75, 1-34. https://doi.org/10.2307/2399464

Gentry, A. H. (1990). Floristic Similarities and Differences between Southern Central America and Upper and Central Amazonia. In A. H. Gentry (Ed.), Four Neotropical Rainforests (pp. 141-157). New Haven, CT: Yale University Press.

Gourlet-Fleury, G., Beina, D., Fayolle, A., Ouédraogo, D. Y., Mortier, F., Bénédet, F., Closset-Kopp, D., \& Decocq, G. (2013). Silvicultural Disturbance Has Little Impact on Tree Species Diversity in a Central African Moist Forest. Forest Ecology and Management, 304, 322-332.

Huang, W., Pohjonen, V., Johansson, S., Nashanda, M., Katigula, M. I. L., \& Luukkanen, O. (2003). Species Diversity, Forest Structure and Species Composition in Tanzanian Tropical Forests. Forest Ecology and Management, 173, 11-24.

Husch, B., Beers, T. W., \& Kershaw, J. A. (2003). Forest Mensuration. New York: Wiley.

Igu, N. I., \& Marchant, R. (2016). Aboveground Carbon Storage in a Freshwater Swamp Forest in the Niger Delta. Carbon Management, 7, 137-148.

https://doi.org/10.1080/17583004.2016.1165355

Ihenyen, J., Okoegwale, E. E., \& Mensah, J. K. (2009). Composition of Tree Species in Ehor Forest Reserve, Edo State, Nigeria. Nature and Science, 7, 8-18.

Ihuma, J. O., Chima, U. D., \& Chapman, H. M. (2011). Tree Species Diversity in a Nigerian Montane Forest Ecosystem and Adjacent Fragmented Forests. ARPN Journal of Agricultural and Biological Science, 6, 17-22.

Keay, R. W. J. (1989). Trees of Nigeria. Oxford, UK: Clarendon Press.

Kelloff, C. L. (2008). Structure and Diversity of a Riparian Forest at Kaieteur National Park, Guyana. Journal of the Botanical Research Institute of Texas, 2, 521-545.

Kent, M., \& Coker, P. (1992). Vegetation Description Analysis. Chichester: Wiley.

Knight, D. H. (1975). A Phytosociological Analysis of Species Rich Tropical Forest on Barro Colorado Islands, Panama. Ecological Monographs, 45, 259-284.

https://doi.org/10.2307/1942424

Koponen, P., Nygren, P., Sabatier, D., Rousteau, A., \& Saur, E. (2004). Tree Species Diversity and Forest Structure in Relation to Microtopography in a Tropical Freshwater Swamp Forest in French Guiana. Plant Ecology, 173, 17-32. https://doi.org/10.1023/B:VEGE.0000026328.98628.b8

Kurtz, B. C., Gomes, J. C., \& Scarano, F. B. (2013). Structure and Phytogeographic Relationships of Swamp Forests of Southeast Brazil. Acta Botanica Brasilica, 27, 647-660. https://doi.org/10.1590/S0102-33062013000400002

Lopez, O. R., \& Kursar, T. A. (2007). Interannual Variation in Rainfall, Drought Stress and Seedling Mortality May Mediate Monodominance in Tropical Flooded Forests. Oecologia, 154, 35-43. https://doi.org/10.1007/s00442-007-0821-0

Magurran, A. E. (1998). Ecological Diversity and Its Measurement. Princeton, NJ: Princeton University Press.

Magurran, A. E. (2004). Measuring Biological Diversity. Oxford: Blackwell.

Malhi, Y., Adu-Bredu, S., Asare, R. A., Lewis, S. L., \& Mayaux, P. (2013). African Rainforests: Past, Present and Future. Philosophical Transactions of Royal Society B., 368. 
Mori, S. A., Boom, B. M., De Carvalino, A. M., \& Dos Santos, T. S. (1983). Southern Bahian Moist Forest. The Botanical Review, 49, 155-232. https://doi.org/10.1007/BF02861011

Ndah, N. R., Andrew, E. E., \& Bechem, E. (2013). Species Composition, Diversity and Distribution in a Disturbed Takamanda Rainforest, South West, Cameroon. African Journal of Plant science, 7, 577-585. https://doi.org/10.5897/AJPS2013.1107

NDES (1997). The Niger Delta Environmental Survey. Environmental and Socio-Economic Characteristics. Lagos, Nigeria: Environmental Resources Managers Limited.

Nzewunwa, N. (1985). Man's Early Interest in, and Use of the Mangrove Ecosystem: The Archaeological Perspective. In B. H. R. Wilcox, \& C. P. Powell (Eds.), The Mangrove Ecosystem of the Niger Delta: Proceedings of a Workshop at the University of Port Harcourt. Port Harcourt.

Ogbemudia, F. O., Etukudo, N. I., \& Ubom, R. M. (2013). Plants Diversity along Watershed Environment: A Case Study at Ikot Uso Akpan Wildlife Sanctuary in Itu L.G.A. of Akwa Ibom State, Nigeria. Annual Review and Research in Biology, 3, 551-563.

Orians, G. H., Dirzo, R., \& Cushman, J. H. (Eds.) (1996). Biodiversity and Ecosystem Processes in Tropical Forests. In Ecological Studies (Vol. 122). Berlin: Springer-Verlag.

Parmentier, I., Malhi, Y., Senterre, B. et al. (2007). The Odd Man Out? Might Climate Explain the Lower Tree Alpha-Diversity of African Rain Forests Relative to Amazonian Rain Forests? Journal of Ecology, 95, 1058-1071.

https://doi.org/10.1111/j.1365-2745.2007.01273.x

Peh, K. S. H., Sonke, B., Séné, O., Marie-Noël, K., Djuikouo, K., Nguembou, C. K., Taedoumg, H., Begne, S. K., \& Lewis, S. L. (2014). Mixed-Forest Species Establishment in a Monodominant Forest in Central Africa: Implications for Tropical Forest Invasibility. PLoS ONE, 9, e97585. https://doi.org/10.1371/journal.pone.0097585

Philips, O. L., \& Gentry, A. H. (1994). Increasing Turnover through Time in Tropical Forests. Science, 263, 954-958. https://doi.org/10.1126/science.263.5149.954

Richards, P. W. (1996). The Tropical Rain Forest: An Ecological Study. Cambridge: Cambridge University Press.

Scarano, F. R., Ribeiro, K. T., De Moraes, L. F. D., \& De Lima, H. C. (1997). Plant Establishment on Flooded and Unflooded Patches of a Freshwater Swamp Forest in Southeastern Brazil. Journal of Tropical Ecology, 13, 793-803. https://doi.org/10.1017/S0266467400011007

Spalding, M., Kainamu, M., \& Collins, L. (2010). World Atlas of Mangroves (319 p). Earthscan.

Udofia, S. I., Owoh, P. W., Attah, V. I., \& Thomas, A. D. (2014). Assessment of Plant Species Composition in Ayan Sacred Forest of Akwa Ibom State, Nigeria. Nigerian Journal of Agriculture, Food and Environment, 10, 34-37.

Valencia, R., Balslev, H., \& Paz Y Mino, G. C. (1994). High Tree Diversity Alpha-Diversity in Amazonian Ecuador. Biodiversity \& Conservation, 3, 21-28. https://doi.org/10.1007/BF00115330

Van Andel, T. R. (2003). Floristic Composition and Diversity of Three Swamp Forests in Northwest Guyana. Plant Ecology, 167, 293-317.

https://doi.org/10.1023/A:1023935326706

Whitmore, T. C. (1998). An Introduction to Tropical Rain Forests (2nd ed.). New York: Oxford University Press. 
Submit or recommend next manuscript to SCIRP and we will provide best service for you:

Accepting pre-submission inquiries through Email, Facebook, LinkedIn, Twitter, etc. A wide selection of journals (inclusive of 9 subjects, more than 200 journals)

Providing 24-hour high-quality service

User-friendly online submission system

Fair and swift peer-review system

Efficient typesetting and proofreading procedure

Display of the result of downloads and visits, as well as the number of cited articles Maximum dissemination of your research work

Submit your manuscript at: http://papersubmission.scirp.org/

Or contact ojf@scirp.org 